\title{
Why Study Problematizations? Making Politics Visible
}

\author{
Carol Bacchi \\ University of Adelaide, Adelaide, Australia \\ Email: carol.bacchi@adelaide.edu.au \\ Received October 27 ${ }^{\text {th }}$ 2011; revised December $8^{\text {th }}$, 2011; accepted January $2^{\text {nd }}, 2012$
}

\begin{abstract}
This paper introduces the theoretical concept, problematization, as it is developed in Foucauldian-inspired poststructural analysis. The objective is two-fold: first, to show how a study of problematizations politicizes taken-for-granted "truths"; and second, to illustrate how this analytic approach opens up novel ways of approaching the study of public policy, politics and comparative politics. The study of problematizations, it suggests, directs attention to the heterogenous strategic relations - the politics - that shape lives. It simultaneously alerts researchers to their unavoidable participation in these relations, opening up a much-needed conversation about the role of theory in politics.
\end{abstract}

Keywords: Problematization; Poststructuralism; Foucault; Public Policy; Comparative Politics; Ethics

\section{Introduction}

At a time when concerns about the knowledge status of research and the role of the researcher are paramount, problematizations provide a fertile field of study. To support this claim I explore the place of problematization in Foucauldian-inspired poststructural analysis. The paper lays out the goals and hopes of this form of inquiry in two parts: first, examining what it means to take problematizations as a focus of analysis; and, second, considering how a study of problematizations translates into research in the fields of public policy, politics and comparative politics. The paper concludes by drawing out the ethical implications of this analytic approach for researchers. Throughout, the intent is to direct attention to the ways in which the study of problematizations opens up innovative research strategies that make politics, understood as the complex strategic relations that shape lives, visible.

\section{Part 1 Studying Problematizations: Goals and Methods}

\section{What Is Problematization? What Are Problematizations?}

The term "problematization" is used in distinct ways in diverse research traditions. Most famously Paulo Freire introduced problematization as a "strategy for developing a critical consciousness” (Montero and Sonn, 2009: 80). For Freire problematization is a pedagogical practice that disrupts taken-forgranted "truths". This objective is accomplished by posing the "myths fed to the people by the oppressors" as "problems" (Freire, 1972: p. 132).

This understanding of problematization as the putting into question of accepted "truths" carries over to Foucault's use of the term, although for Foucault and the forms of poststructural analysis that draw on his work, problematization is more a description of thinking as a practice than a diagnosis of ideological manipulation. As developed below, in poststructural accounts, problematizations are to be treated, not as illusions that can be unveiled by "clever philosophical investigation", but as the thinking that comes to constitute our condition (Koopman,
2007). Nonetheless, Freire and Foucault share a conviction to approach questions differently, not to argue pro or con a specific position, but to inquire into the terms of reference within which an issue is cast-into its "problematization". 1

Foucault employs the term "problematization" in two ways: first, to describe his method of analysis and, second, to refer to a historical process of producing objects for thought. His particular method of analysis, which he calls "thinking problematically” (Foucault, 1977: pp. 185-186), is the method just described, where the point of analysis is not to look for the one correct response to an issue but to examine how it is "questioned, analysed, classified and regulated" at "specific times and under specific circumstances” (Deacon, 2000: p. 127). In the second meaning problematization captures a two-stage process including "how and why certain things (behavior, phenomena, processes) become a problem” (Foucault 1985a: p. 115), and how they are shaped as particular objects for thought (Deacon, 2000: p. 139; see also Deacon, 2006: p. 186 fn 2). These problematized phenomena become problematizations, the foci for study. ${ }^{2}$

For example, in his History of Sexuality, Foucault (1980a) asks how different eras have problematized sexuality and thus made sexuality a particular kind of object for thought in different sites. His focus is "the historical study of the way in which domains we call sexuality - that is analyses and experienceshave been formed" (Foucault in Mort and Peters, 2005: pp. 12-13). Particular attention is directed to the shaping influence of the various modern bodies of knowledge about "sexuality" (various "sciences of sexuality", including psychoanalysis) and to the political structures, laws, requirements and regulations surrounding sexual practices. For Foucault (1984), in effect, "sexuality" does not exist as an object for thought outside the

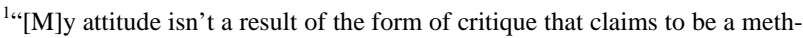
odological examination in order to reject all possible solutions except for the one valid one. It is more on the order of 'problematization'-which is to say the development of a domain of acts, practices and thoughts that seem to me to pose problems to politics" (Foucault, 1984).

2"The archaeological dimension of the analysis made it possible to examine the forms of problematization themselves, its genealogical dimension enabled me to analyze the formation out of the practices and their modifications” (Foucault, 1986: pp. 17-18). 
relationships forged by these knowledges and regulations. Therefore, to understand how "sexuality" has come to be accepted and treated as a designated human characteristic, we need to study "the practices, political structures and ethical forces which 'constitute"” "sexuality" as an object for thought (Carelle, 2000: p. 131). This is accomplished by studying "sexuality" as a problematization.

As another example, in his history of madness (Foucault, 1972a), Foucault asks "how and why were very different things in the world gathered together, characterized, analyzed, and treated as for example 'mental illness'?” The answer to this question provides the "elements" deemed relevant "for a given 'problematization'” (Foucault, 1985a: p. 115):

It was a matter of determining the role of politics and ethics in the establishment of madness as a particular domain of scientific knowledge [connaissance], and also of analyzing the effects of the latter on political and ethical practices (Foucault, 1984: p. 8).

The goal here is to make the criteria that "establish" the object "madness" more noticeable. Such an intervention undermines its taken-for-granted status as "true" and "real". It opens up for examination both the complex relations that produced it and the effects of its operation (Veyne, 1997: p. 154).

The main purpose of studying problematizations, therefore, is to "dismantle" objects (e.g. "sexuality", "madness") as takenfor-granted fixed essences (Foucault, 1991a [1981]: p. 29 in Rabinow, 2009: p. 29) and to show how they have come to be. Each of Foucault's methodological interventions-archaeology, genealogy, discursive practices (Bacchi and Bonham, 2011) and problematization-shares this objective. Foucault (1991b: p. 86) describes himself as a historical nominalist for whom the terms "madness" and "sexuality" (and others, such as "delinquency”, "power”, "man”, "the state”) are simply the names that one attributes to "complex strategical situations in a particular society" (Foucault, 1980a [1978]: p. 93 in Alasuutari, 2010: p. 407). Studying how these "things" emerge in the historical process of problematization puts their presumed natural status in question and allows us to trace the relations-“connections, encounters, supports, blockages, plays of forces, strategies on so on" (Foucault 1991b: p. 76) - that result in their emergence as objects. In effect, relations replace objects (Veyne, 1997: p. 181).

What is the political point of this stratagem? Foucault's particular concern is how governing takes place: "My problem is to know how men (sic) govern (themselves and others) by means of the production of truth" (Foucault, 1980b: p. 47 in Castel, 1994: p. 238). "Objects" such as "sexuality" and "madness" are central to how we are governed because they have all sorts of effects on the ways we live our lives-both directly and indirectly through the norms they install. Therefore disrupting their taken-for-granted status as truth opens up relations of ruling for critical scrutiny. A further political consequence is that, since relations are in flux, as opposed to the presumed fixity of objects, more room to maneuver is created. History, in this view, is crossed by heterogeneous strategic relations that consequently are mobile and can be changed.

Foucault starts his analysis from a "problem" in the present, producing a "history of the present" (Flynn, 2005: p. 45). For example, Foucault was directly involved in campaigns to reform contemporary French prisons ${ }^{3}$; they became his "problem" in

${ }^{3}$ Foucault was very active politically in the 1970 s, founding the Groupe d'information sur les prisons (Gutting, 2008). the present. To put the status of contemporary French prisons in question he "thinks problematically", looking to see how systems of punishment were problematized in the past and tracing how current imprisonment practices relate to those earlier "problematizations". 4

Foucault selects his sites-his "problematizing moments"by identifying times and places where he detects important shifts in practices - for example from flogging to detention. As Flynn (1989a: 138) explains, for Foucault, "The problem in the case at hand is to account for the fact that from about 1791 a vast array of penal methods was replaced by one, incarceration". In these "crisis” moments (Foucault, 1985a: Chapter 2), "givens" become questions, or problems, providing an opportunity to inquire into the emergence of what comes to appear selfevident because it is firmly in position, in this instance incarceration as a method of punishment. ${ }^{5}$

Importantly, the problematizations Foucault studies are not driven by shifting historical circumstances, such as industrialization or urban growth. ${ }^{6}$ But nor are problematizations simply free-floating ideas that answer to nothing, "pure dream, or an 'anti-creation'”. A problematization is always "a kind of creation”, Foucault tells us, but "a creation in the sense that, given a certain situation, you cannot infer that this kind of problematization will follow" (Foucault, 1985a). There is nothing inevitable about it. That is, there are always exigencies that affect how developments take place, putting emphasis on the politics, the contestation, the strategic relations involved in those developments. By studying problematizations therefore it is possible

to demonstrate how things which appear most evident are in fact fragile and that they rest upon particular circumstances, and are often attributable to historical conjunctures which have nothing necessary or definitive about them (Foucault in Mort \& Peters, 2005: p. 19).

Rendering fixed "objects" "fragile" is particularly important because they shape our experience of "who we are and what we know" (May, 2006: p. 104), a process Foucault calls "subjectivation” (Flynn, 1985). To understand how problematizations provide entry-points for reflecting on this process, it is necessary to examine the relationship between problematizations and practices.

\section{How to Identify Problematizations: The "Turn to Practice"}

Foucault tells us that problematizations emerge in practices; they are not simply mental images or ideas. He describes "the problematization of madness and illness arising out of social and medical practices" and "a problematization of crime and criminal behavior emerging from punitive practices” (Foucault, 1986: p. 12; emphasis added). But what then are practices? And how do problematizations "emerge" from them?

Foucault describes "practices" as "places" where "what is said and what is done, rules imposed and reasons given, the planned

${ }^{4}$ Foucault describes this form of study as genealogy: "I start with a problem in the terms in which it is currently posed and attempt to establish its genealogy; genealogy means that I conduct the analysis starting from the present situation” (Foucault, 1988: 262; emphasis added).

${ }^{5}$ The next section of the paper elaborates the key role played by the concept "practice" in Foucault's analysis.

6" But we have to understand that a given problematization is not an effect or consequence of a historical context or situation, but is an answer given by definite individuals (although you may find that same answer given in a series of texts, and at a certain point the answer may become so general that it becomes anonymous)” (Foucault, 1985a: Concluding Remarks). 
and the taken for granted meet and interconnect" (Foucault, 1991b: p. 75). ${ }^{7}$ They have a judicative component, establishing and applying norms, controls and exclusions ("rules imposed"), and a "veridicative" component, rendering "true/false" discourse possible ("reasons given”) (Flynn, 2005: p. 31). Thus, "the practice of legal punishment... entails the interplay between a 'code' that regulates ways of acting-such as how to discipline an inmate- and the production of true discourse that legitimates these ways of acting” (Flynn, 2005: p. 31; emphasis added). People are involved in practices of this sort every day and all the time, for example, in carrying and displaying a driver's license, going to school or getting married.

The term "practice" therefore describes the "intelligible background" for actions-which Foucault calls "thought”- “a preconceptual, anonymous, socially sanctioned body of rules that governs one's manner of perceiving, judging, imagining and acting” (Flynn, 2005: p. 31). ${ }^{8}$ Hence, practices shape emergent individuals and relations. Through practices, we are constituted as particular kinds of subjects, while the multiplicity of practices ensures the always incomplete nature of these subjectivation processes (Eveline \& Bacchi, 2010: pp. 139-141).

Thought, as understood here, is "not merely a mental, cognitive, speculative, or linguistic phenomenon"; rather, it is a "set of practices in its own right", that is, "a process that participates in the constitution of the objects of which it speaks, and that has specific and identifiable political effects" (Deacon, 2000: p. 132). This position challenges a theory/practice divide. Theory is itself a practice, "part of the process that constitutes or problematizes reality” (Deacon, 2000: p. 134). The implications of this stance for researchers are pursued in the conclusion to the paper.

The relationship between practices and problematizationshow problematizations emerge from practices-is explained most clearly in a 1969 pamphlet written as part of Foucault's application for a Chair of Systems of Thought at the Collège de France. Here he explains that he "wanted to determine what could be known about mental illness at a given period" (Foucault, 1969 in Eribon, 1991: p. 214; emphasis added). He acknowledges the traditional sources of such "knowledge", that is, medical theories and "opinion". However he deduces that there is "a dimension that seemed unexplored"- the actual practices involving those designated "mad":

how madmen were recognized, set aside, excluded from society, interned, and treated; what institutions were meant to take them in and keep them there, sometimes caring for them; what authorities decided on their madness, and in accordance with what criteria; what methods were set in place to constrain them, punish them, or cure them; in short, what was the network of institutions and practices in which the madman was simultaneously caught and defined (Foucault, 1969 in Eribon, 1991: p. 214).

These practices reveal how an issue ("madness") is questioned, analyzed, classified and regulated-how it is problematized. Hence, we can study the emergence of "madness" as an object of knowledge by examining the practices that classify

\footnotetext{
${ }^{7}$ Practice is a key term in Foucault's earlier and later work, bridging what many see as significant shifts in his analysis. It is a difficult concept that needs some attention given the diverse meanings of the "turn to practice" in much contemporary social theory (Oswick et al., 2007; Simpson, 2009).

${ }^{8}$ Importantly, Foucault's “rules” are not principles of organization or structures (compare Fairclough, 1992: 57), but sets of relationships, “a complex group of relations that function as a rule" (Foucault, 1972b: 74; emphasis added).
}

and regulate, that problematize and constitute, those designated "mad". The suggestion here is that it is possible to get at "knowledge" ("what could be known") about "madness", through examining what is done, how the "mad" are dealt with. "Knowledge", as understood here, is something immanent to what people $d o$, not a transcendent phenomenon, waiting to be discovered. ${ }^{9}$

By turning to practices, therefore, Foucault is looking to carve out a space between realism and idealism. That is, he postulates that there is something "real" being regulated-but it is not "madness", which does not exist as an object for thought until it is produced through practices. At the same time we are not talking simply about ideas or attitudes, a mental perception of what it means to be "mad". Rather we are talking about how "madness” is "thought”, “conceptualized”, "problematized”, as demonstrated through how the "mad" are dealt with as a specific kind of phenomenon. In this way attention is directed to the mechanisms involved in collecting together things, actions, gestures, behaviours, words that are to make up "madness" as "the real". 10

Foucault's method for accessing problematizations, therefore, starts from practices:

Rather than perusing the library of scientific books, as one so happily does, I had to visit a group of archives including decrees, regulations, hospital or prison registers, judicial precedents. Working at the Arsenal or the National Archives, I began the analysis of a knowledge whose visible body is neither theoretical or scientific discourse nor literature, but a regular, daily practice (Foucault, 1969 in Eribon, 1991: p. 216).

Foucault calls these regulations and decrees "practical texts" or "prescriptive texts", "written for the purpose of offering rules, opinions, and advice on how to behave as one should" (Foucault, 1986: pp. 12-13). We can think here of Foucault's description of practices as "places" where "rules imposed and reasons given” meet and interconnect (see above). Moreover, these texts are themselves the "object of a 'practice' in that they were designed to be read, learned, reflected upon, and tested out, and they were intended to constitute the eventual framework of everyday conduct” (Foucault, 1986: pp. 12-13). To inquire into how governing takes place, therefore, the place to start is the problematizations within these practical guides to practice, focusing on how they problematize an issue or experience. From this starting place it becomes possible to tease out the complex strategic relations that produce "things".

\section{Problematizations, “Truth” and Subjectivity}

Foucault has specific practices in mind when he undertakes the study of problematizations. He focuses on practices involved in governing (understood broadly), practices that "contain institutionally legitimated claims to truth” (Rabinow, 2003: 20; emphasis added). As Flynn (1989b: p. 189) describes, Foucault's intent is to "reveal the chance crossings of lines of governance (institutions, practices, attitudes), the brute facts and contingencies at the base of our most cherished values and most respected necessities". To this end he targets historical conjunctures, e.g. the emergence of modern prison practices, the

${ }^{9}$ As O'Farrell (2005: p. 22) explains, Foucault is opposed to the idea of "thought" as something divorced from action and from material existence: "Every human institution and action activates some form of thought, even if the individual practising that action is not aware of the thought they are putting into play".

${ }^{10}$ The author would like to thank Jennifer Bonham for elucidating this point. 
institutionalization of "the mad" and the regulation of "sexuality", that raise power/knowledge challenges to those governing.

In Foucault, as we have seen, "madness" and "sexuality" do not exist as fixed and autonomous essences; rather, they "become", they "emerge", as objects for thought in practices. Studying problematizations, therefore, allows one to consider the relations involved in their emergence through examining how they are "thought" (remembering that thought refers to a material practice not to a mental image). One starts on the surface with practices, and observes how these practices render complex relational phenomena problematic (as "problems"), in the process producing them as "objects" (e.g. as "sexuality", "madness"). Foucault describes problematization in exactly these terms:

Problematization doesn't mean the representation of a preexisting object, nor the creation through discourse of an object that doesn't exist. It is the set of discursive and non-discursive practices that makes something enter into the play of the true and the false and constitutes it an object for thought (whether under the form of moral reflection, scientific knowledge, political analysis, etc.) (Foucault, 1988: p. 257). ${ }^{11}$

The reference to making "something enter into the play of the true and the false" relates to Foucault's position on "truth" and "truth games". For Foucault (1985b), telling the truth is like playing a game because, as in a game, there are no outside criteria by which to judge its content; "truth" is shaped by internal rules (Franchi, 2004). When he speaks about the "production of truth", therefore, he means, not the "production of true statements", but the "administering of the realms" (setting up the "rules of the game") in which the production of the true and the false is regulated. This intervention places the production of these rules "at the heart of historical analysis and political debate” (Foucault, 1980b: p. 47 in Castel, 1994: p. 238).

Alerting "game-players" (all of us) to the "internal rules" that shape the emergence of "real" "objects", achieved through the study of problematizations, is a crucial political intervention. Through this analytic gesture one comes to understand how something (e.g. "sexuality", "madness") has come to be "true" or, more precisely, as "in the true". ${ }^{12}$ This task is complicated, however, by the norms embedded in practices-the "rules one prescribes to oneself and the reasons one ascribes" (Foucault, 1980b: p. 42 in Flynn, 2005: p. 31)-that "determine how we go about constructing who we are and what we know" (May, 2006: p. 104). That is, since we are all located within practices and problematizations that shape us to an extent, it is difficult to stand back and study their operation. For example, Foucault (1980a) argues that specific problematizations of sexuality-e.g. sexuality as moral code, sexuality as biological imperativeenjoin people to become particular kinds of sexual subjects.

This argument challenges the more conventional view that normative intervention in people's lives takes place through prohibitions and interdictions. ${ }^{13}$ It also elucidates Foucault's much misunderstood position on power. True to his nominalist stance, power is not a thing but the name attributed to plural and diffuse strategic relations. These strategic relations can

\footnotetext{
${ }^{11}$ There is considerable debate about Foucault's distinction between discursive and non-discursive practices, canvassed in Bacchi and Bonham (2011). They make the case that "discursive practices" in Foucault refer to knowledge not language, meaning that non-discursive practices are practices not specifically related to forms of sanctioned knowledge.

${ }^{12}$ As Flynn (1989a: 135) explains, “A focus on practices enables statements to be assessed as true or false, as valid or invalid, as authoritative or not without presuming that there is any a-contextual reality to which they refer.”
}

both restrain and produce. The productive effects of power are observed through problematizations, as in the example just given of the production of particular kinds of sexual subject. In this stance, the subject is "distilled" "into the points of intersection of various practices” (Flynn, 1989a: p. 141), in stark contrast to the humanist conception of a coherent, knowing consciousness (Eveline \& Bacchi, 2010: p. 150).

Problematization as a method (thinking problematically) involves studying problematized "objects” (“problematizations”) and the (historical) process of their production. It involves "standing back" from "objects" and "subjects", presumed to be objective and unchanging, in order to consider their "conditions of emergence" and hence their mutability. Foucault (1984) argues that thinking in this way produces a kind of freedom, "freedom in relation to what one does, the motion by which one detaches oneself from it, establishes it as an object, and reflects on it as a problem". Through this detachment there emerges the possibility of gaining a sense of the "implicit system in which we find ourselves", of "the system of limits and exclusions we practice without realizing it", and thus "to make the cultural unconscious apparent” (Simon, 1971: p. 73 in O’Farrell, 2005: p. 69).

However, because there is no place outside practice from which to make this intervention, "it must be a matter of looking at the unfolding, the evolution and the interaction of different practices” (May, 2006: p. 19). Problematizations offer the best hope for considering this "unfolding" because they engage us in studying the times and places when "things" are contested and "real” "objects" emerge. Moreover, as itself a practice, the study of problematizations can generate alternative ways of being. ${ }^{14}$ The next part of the paper explores how this form of analysis translates into research in the fields of public policy, politics and comparative politics.

\section{Part II Problematizations in Policy and Politics: Applications}

\section{Policy Studies}

Taking her lead from Foucault and the concept of problematization Bacchi (1999, 2009) develops an approach to policy analysis that focuses on problematizations. Her "what's the problem represented to be?" (WPR) approach states that it is possible to use public policies and policy proposals as starting places to access the problematizations through which we are governed. The approach picks up and develops Foucault's suggestion that "practical" or "prescriptive" texts provide entrypoints for identifying problematizations. For Bacchi every policy or policy proposal is a prescriptive text, setting out a practice that relies on a particular problematization (or particular problematizations). She coins the term "problem representation" to refer to the form of a problematization - the problematized phenomenon - in a specific site.

The WPR approach rests on a basic premise - that what we say we want to do about something indicates what we think needs to change and hence how we constitute the "problem". Following this thinking Bacchi argues that it is possible to take any policy proposal and to "work backwards" to deduce how it produces a "problem". ${ }^{15}$ For example, there are currently many

\footnotetext{
${ }^{13}$ This is Foucault's famous challenge to the "repressive hypothesis".

${ }^{14}$ This endorsement of the study of problematizations as a critical practice is in keeping with Foucault's later work on "practices of the self" (Martin, Gutman, \& Hutton, 1988).
} 
plans of action that offer women training in order to increase their likelihood of acquiring positions of status or higher paying jobs. Such proposals make women's lack of training the "problem". With this starting place, it becomes necessary to explore the terms of reference within which the issue is cast-that is, to study its problematization. To open up problematizations for critical scrutiny, Bacchi (2009: p. 2) introduces a series of questions designed to tease out conceptual premises, to draw attention to the "history" (genealogy) of specific problematizations, and to consider their effects, including subjectification effects, ${ }^{16}$ for how people live their lives. This focus on the implications or effects of problematizations sets this mode of analysis apart from relativist stances.

The WPR approach broadens Foucault's agenda. It does not look for "crisis" points, places where practices change, stirring up debate. Rather, it suggests that all policy proposals rely on problematizations which can be opened up and studied to gain access to the "implicit system in which we find ourselves". As with Foucault, the point is not to stake out a position "pro" or "con" a specific stance, nor to identify the "real" "problem", but to explore "the system of limits and exclusions we practice without realizing it” (Simon, 1971: p. 73 in O’Farrell, 2005: p. 69). To this end the goal is to stand back from taken-for-granted objects and concepts to determine how they have come to be through studying the heterogeneous strategic relations-the politics - that have gone into their making. The WPR approach also incorporates Foucault's suggestion that it is possible to detect patterns in problematizations, revealing modes or styles of governing that shape lives and subjectivities. This analytic focus is pursued in governmentality studies.

\section{Governmentality Studies}

As mentioned earlier, Foucault's particular concern is how governing takes place and, to this end, he studies the practices of governing. Our examples so far include the governing of "madness" and of "sexuality". However, more conventional techniques of governing, such as the policy of health and welfare of the population, or the use of statistics in calculating and identifying political subjects, can be subjected to the same kind of analysis. The goal in each case is to access the "thought" in governing practices. As discussed earlier, thought here is conceived, not as what goes on in people's heads, but as "a set of practices in its own right", participating in the constitution of the objects and subjects of which it speaks (Deacon, 2000: p. 132). Problematizations, as we have seen, provide entry-points for reflecting on this "thought" and the role it plays in constituting kinds of subjects and forms of "object" that make rule possible.

In his studies of governmental practices, Foucault detects styles of problematization, described variously as "grids of intelligibility”, "interpretive grids” (Castel, 1994: p. 148), "govern-mentalities" or "political rationalities". Rationality in this context refers not to the exercise of reason but to the rationales for rule that make the activity of government both thinkable and practicable (Gordon, 1991: p. 3). For example, Foucault identi-

\footnotetext{
${ }^{15}$ Bacchi (2009) expands her analysis to encompass theoretical propositions, which in her view are proposals for action that presume certain "problems". She therefore applies the WPR approach to criminal justice theory (101-102) to health policy theory (128-140), to gambling policy theory (249-250), and to policy studies theory (249-255).

16“'Subjectification” is Bacchi's (2009: 16-17) term for Foucault's "subjectivation”.
}

fies a new "rationale" at work, "punitive reason", in the shift from a "vast array of penal methods" to "incarceration" in 1791. Govern-mentalities, then, are the ways in which rule is rationalized and rendered "effective". They are "diagrams" of rule (Deleuze, 1988: p. 44) that "seek to shape conduct by working through our desires, aspirations, interests and beliefs” (Dean, 1999: p. 11). Importantly these rationalities (or rationales) are not restricted to conventional governmental institutions; rather, the role of professionals and professional knowledges in governing processes is emphasized. This focus is illustrated in the following examples of governmentality studies.

Rose (2000: p. 12) examines a mode of governing common to liberalism and to neoliberalism, which he calls "advanced liberalism”, that emphasizes individual responsibility and independence. Individual "responsibilisation” (Bacchi, 2009: pp. $118,134,157)$ has emerged as a mode of rule in criminal justice policy, in drugs/alcohol and gambling policy, and in much health policy in contemporary industrialized countries. Walters (2004) identifies security as a dominant motif in national and international governance, seen in the current focus on "energy security”, "food security” and "water security”, alongside more conventional foreign policy security concerns. Along similar lines Bigo (2002) talks about a current "governmentality of unease”. In relation to regimes of governing justice, Garland (2001) describes a shift from "penal welfarism”, as a governmental rationality, that, in his view, dominated the 1960s and 1970 s in the UK and the USA, to a more recent "culture of control”. St Pierre (2006: p. 259) identifies evidence-based research as a form of governmentality, "a mode of power by which state and complicit nonstate institutions and discourses produce subjects that satisfy the aims of government policy". Bacchi (2009: pp. 252-255) describes evidence-based policy as part of a broader problem-solving motif currently dominating the intellectual and policy landscape of western industrialized societies. Putting a particular focus on subjectivation Clough (2007: pp. 62, 74) identifies a "rationality of affectivity" that governs through "pre-individual capacities to affect and be affected".

Angelique Bletsas (2012, forthcoming) draws attention to what is novel in the study of governmentalities through her analysis of contemporary debates about the place of poverty in current political regimes, shaped, she argues, by an "affluence governmentality”. She points out that the task in governmentality studies is not simply to identify how different groups conceptualize poverty (as either a "problem" of individuals or a "problem" of structures) but to recognize how rule takes place through one or other of those conceptualizations. Governing takes place through particular problematizations, raising a raft of new questions, such as:

How did poverty come to be seen as a "problem" for governments and other experts to address? Why is it poverty, and not some related issue-inequality, wealth, etc.- that has come to be seen as the "problem"? What forms of governing practice (surveillance, discipline, self-government, etc.) are enabled where poverty is constructed in this way as a problem? What are the effects of this formation-including, and in particular, the lived effects for those who are poor? (Bletsas 2012, forthcoming).

Governmentality studies adhere to Foucault's nominalist critique (Alasuutari, 2010). "The state” is conceptualized as a "mythical abstraction" (Rose and Miller, 1992: p. 173), an anchor point for myriad strategic relations that merge in specific 
political forms, rather than an entity with a presumed essential necessity or functionality. Demonstrating a poststructuralist sensitivity to fluidity and contestation in social thought and relations, such studies challenge the reliance of conventional political "science" on homogenous, fixed categories, such as "nation-state". Accepting that theory itself is a practice that plays a key role in producing the "real" (see above), the further implication is that such reliance reinforces a "reality" of "nation-states" (Law, 2004: p. 144), with important power effects for both those deemed to be members or non-members.

As an alternative, governmentality studies detail the heterogeneous strategic relations that go into the making of specific "states", opening up spaces for intervention and movement. For example, the poststructualist scholar, Rowse (2009), describes nation-states as methods for assembling power relations. ${ }^{17}$ Such a reconceptualization provides an opening to problematize "sovereignty in world politics as well as in research practice itself” (de Goede, 2006: p. 5). This recommended shift from static entities to strategic relations promises to open up a whole new field for comparative politics.

\section{Comparative Politics}

Conventional comparative politics presumes a fixity of "nation-states" in order to set up comparisons "between" and "among" them. Hence, as argued above, such studies tend to reinforce "states" as political realities. By contrast a comparison of problematizations keeps relations in flux and alerts researchers to the politics involved in accepting and hence reinforcing entities, such as "states" or "institutions", as stable and legitimate (Bacchi \& Rönnblom, 2011).

Moreover, comparing problematizations across time, across "cultures" or across geophysical "spaces" shifts attention from how specific bordered entities "compare" on identifiable factors or "indicators" to consideration of how an issue looks quite different in different locales. Hence, such comparisons can illustrate that certain ways of thinking about "problems" reflect specific institutional and cultural contexts. In this way comparing problematizations promises to address Christopher Bosso's (1994: p. 200) request that we ask more questions about the "dog that did not bark", posed by Sherlock Holmes in the "Mystery of Silver Blaze”.

For example, Pálsson and Rabinow (2006) compare how the collection of biometric data was problematized quite differently in Iceland, undertaken post-1998, where there was a highly polarized debate, and in Britain, where a plan to collect similar kinds of data attracted very little attention. They found that a key factor was that, in the two countries, there was a different relationship between physicians and parliament in the regulation of human research. In their view, there was no protest in the UK because there the "funders of research, the managers of the data base and the regulators can be in the same institutions" (Kaye \& Martin, 2000 in Pálsson \& Rabinow, 2006: p. 100).

Comparisons of problematizations, such as this one, highlight the specific combinations of factors and relations that allow something to become a "problem" in one situation and not in another. While "nation-states", here the UK and Iceland, are used as identifiers of sorts in the analysis, the focus

\footnotetext{
${ }^{17}$ Rowse (2009) borrows the concept of "method assemblage" from John Law. A method assemblage includes "not only what is present in the form of texts and their production, but also their hinterlands and hidden supports" (Law, 2004: 144).
}

throughout is on the interconnections, the relations, the movement that results in specific effects in specific "places". These effects are understood as contingent and open to re-thinking, rather than as "true" or "real". There is no suggestion that "nation-states" ought to be treated as variables in some attempt to predict "outcomes" in other settings. The objective is to make politics visible rather than to generate "knowledge".

Uma Narayan's (1997) examination of contrasting problematizations of sati, or "widow burning”, accomplishes exactly this goal. Narayan compares how sati is conceptualized (problematized) differently in what she calls the "colonialist stance" and among contemporary Indian feminist critics. In contrast to the latter, the "colonialist stance" ignores past political contestation and produces generalizations about the role of "tradition" and "Third World Patriarchal Cultural Practices" in the practice of sati. Narayan (1997: pp. 59-60; Lazreg, 1988 in Narayan, 1997: p. $60 \mathrm{n} 29$ ) argues that such generalizations are damaging to the women involved since treating "traditions" as fixed and unchanging forecloses "any analysis of change". In her view (2000: 86) "cultures" and "traditions" ought to be conceived as political projects, rather than as static entities, “'frozen' with respect to both space and time” (Narayan, 1997: p. 50). To undermine the power of such essentialist categories and their anti-feminist repercussions, Narayan calls for a strategy of returning history and politics to the emergence of "cultures" and "traditions". This strategy involves producing genealogies of problematizations.

\section{Conclusion: Implications for Researchers}

For Narayan, different forms of analysis-e.g. "the colonialist stance" versus "genealogies of problematizations"-have political repercussions that should become part of the study of politics. She shows how a focus on problematizations promises to reveal the exigencies and contestation involved in the production of oppressive practices which conventional approaches to "tradition" and "culture" ("the colonialist stance") tend to reinforce. The same point was made above in the contention that conventional political science studies that treat "nationstates" as givens tend to reinforce existing geopolitical power relations. In this view theories, as practices, produce forms of problematization that create objects and subjects necessarily involved in how rule takes place.

This position is defended and elaborated by Annemarie Mol (1999) and John Law (2004, 2008), who develop the concept of "ontological politics" to draw attention to the political effects of theory practices (see Bacchi, 2012, forthcoming). ${ }^{18}$ According to Mol (2002), multiple realities are produced through plural, heterogeneous practices, raising questions about the "singular reality" that emerges from this multiplicity. The "singularity of objects" turns out to be "an accomplishment", an act of "coordination” (Mol, 2002: pp. 7-8), with research methods identified as major players in the reinforcement of particular realities. Says Mol (2002: p. 155; emphasis in original), "[M]ethods are not a way of opening a window on the world, but a way of interfering with it. They act, they mediate between an object and its representations".

If, as argued here, the concepts and arguments developed by researchers play a key role in establishing what is "in the true" and hence "real", those researchers ought surely to be encour-

\footnotetext{
${ }^{18}$ Law (2008a, 2008b) and Mol (1999) are leading theorists of the "turn to practice”, discussed earlier in the paper, and of actor-network theory.
} 
aged to consider the repercussions of their research in these terms. Understanding power as creative/productive and theory as practice creates an ethical obligation to consider the political fallout of our theoretical investments. It means confronting the political implications that accompany the reification of "nation-states”, "sexuality”, “culture”, "tradition” and other categories (Veyne, 1997: p. 167). It means asking-what realities do my methods create and with what effects for which creatures and places?

The practice of studying problematizations encourages exactly this form of critical reflexivity. Such a practice prompts researchers to keep a critical eye to their own analyses, which can only ever be part of a problematization. To encourage this self-scrutiny, Bacchi (2009, 2011) builds self-problematization into the WPR approach by including an undertaking to apply its questions to one's own presuppositions and assumptions. The suggestion here is that "to problematize reality or to write a history of the present is as much to transform oneself as it is to make objects of reason present” (Deacon, 2000: p. 137). ${ }^{19}$

A study of problematizations, therefore, offers researchers the possibility of getting inside thinking -including one's own thinking-observing how "things" come to be. It gives access to the spaces within which "objects" emerge as "real" and "true", making it possible to study the strategic relations, the politics, involved in their appearance. Examining thought in this way puts into question the presumed fixity of the thing "thought" and, by so doing, makes it possible to think otherwise: "It radicalises our sense of the contingency of our dearest biases and most accepted necessities, thereby opening up a space for change” (Flynn, 2005: p. 33).

In this research approach, problematizations are recognized as powerful and yet contingent ways of producing the "real". In effect governing takes place through problematizations, emphasizing the importance of subjecting them to critical scrutiny and pointing to the possible deleterious effects they set in operation. Such scrutiny "involves the multiplication of further problematizations, such that we are constantly alerted to the task of an on-going ethic of the problematic as a sort of critical virtue in itself" (Osborne, 2003: p. 15). Such an ethic directs attention to the political effects of forms of explanation, opening up a much-needed conversation about the role of theory in politics.

\section{Acknowledgements}

The author would like to thank Angelique Bletsas, Jennifer Bonham and Anne Wilson for comments on earlier drafts of this paper.

\section{REFERENCES}

Alasuutari, P. (2010). The nominalist turn in theorizing power. European Journal of Cultural Studies, 13, 403-417. doi:10.1177/1367549410377579

Bacchi, C. (1999). Women, policy and politics: The construction of policy problems. London: Sage.

Bacchi, C. (2009). Analysing policy: What's the problem represented to $b e$ ? Frenchs Forest, NSW: Pearson Education.

Bacchi, C. (2011). Gender mainstreaming and reflexivity: Asking some hard questions. Keynote address at the Advancing Gender+ Training

\footnotetext{
19"What was at stake was not just a question of the formal accretion of knowledge but an exercise in one's relation to truth that was thereby also an exercise in self-transformation and ultimately transgression” (Osborne, 2003 p. 12).
}

in Theory and Practice Conference: An International Conference for Practitioners, Experts and Commissioners in Gender+ Training. Madrid: Complutense University.

Bacchi, C. (2012). Strategic interventions and ontological politics: Research as political practice. In: A. Bletsas and C. Beasley (Eds.), Engaging with Carol Bacchi: Strategic interventions and exchanges. Adelaide: University of Adelaide Press.

Bacchi, C., \& Bonham, J. (2011). Reclaiming discursive practices as an analytic focus: Political implications. Geography, Environment and Population Seminar Series. Adelaide: School of Social Sciences, University of Adelaide.

Bacchi, C., \& Rönnblom, M. (2011). Feminist discursive institutionalism-What's discursive about it? Limitations of conventional political studies paradigms. $2^{\text {nd }}$ European Conference on Politics and Gender, Budapest, 13-15 January.

Bigo, D. (2002). Security and immigration: Toward a critique of the governmentality of unease. Alternatives: Global, Local, Political, 27, 63-92.

Bletsas, A. (2012). Spaces between: Elaborating the theoretical underpinnings of the WPR approach and its significance for contemporary scholarship. In A. Bletsas, \& C. Beasley (Eds), Engaging with Carol Bacchi: Strategic interventions and exchanges. Adelaide: University of Adelaide Press.

Bosso, C. J. (1994). The contextual bases of problem definition. In D. A. Rochefort, \& R. W. Cobb (Eds), The politics of problem definition: Shaping the policy agenda (pp. 182-203). Lawrence, KS: University Press of Kansas.

Carelle, J. R. (2000). Foucault and religion: Spiritual corporality and political spirituality. London and New York: Routledge.

Castel, R. (1994). "Problematization" as a mode of reading history. In J. Goldstein (Ed.), Foucault and the writing of history (pp. 237-252). Oxford, UK: Blackwell.

Clough, P. T. (2007). Notes towards a theory of affect-itself. Ephemera: Theory \& Politics in Organization, 7, 60-77.

Deacon, R. (2000). Theory as practice: Foucault's concept of problematization. Telos, 118, 127-142.

Deacon, R. (2006). Michel Foucault on education: A preliminary theoretical overview. South African Journal of Education, 26, 177-187.

Dean, M. (1999). Governmentality: Power and rule in modern society. London: Sage.

De Goede, M. (2006). International political economy and the promises of poststructuralism. In M. de Goede (Ed.), International political economy and poststructural politics (pp. 1-20). Houndmills: Palgrave Macmillan.

Deleuze, G. (1988). Foucault. Minneapolis: University of Minnesota Press.

Eveline, J. and Bacchi, C. (2010) Power, resistance and reflexive practice. In C. Bacchi, \& J. Eveline (Eds), Mainstreaming politics: Gendering practices and feminist theory (pp. 139-161). Adelaide: University of Adelaide Press.

Eribon, D. (1991). Michel Foucault. London: Faber and Faber.

Fairclough, N. (1992). Discourse and social change. Cambridge, MA: Polity Press.

Flynn, T. R. (1985). Truth and subjectivation in the later Foucault. The Journal of Philosophy, 82, 531-540. doi:10.2307/2026360

Flynn, T. R. (1989a). Foucault and historical nominalism. In H. A. Durfee, \& D. F. T. Rodier (Eds), Phenomenology and beyond: The self and its language (pp. 134-147). Netherlands: Kluwer. doi:10.1007/978-94-009-1055-3 10

Flynn, T. R. (1989b). Foucault and the politics of postmodernity. Noûs, 23, 187-198. doi:10.2307/2215978

Flynn, T. R. (2005). Foucault's mapping of history. In G. Gutting (Ed.), The Cambridge companion to Foucault (pp. 29-48, 2nd ed.). Cambridge: Cambridge University Press.

Foucault, M. (1969). Pamphlet submitted to Professors of the Collège de France, cited in D. Eribon (1991). Michel Foucault (pp. 214-216). B. Wing (Trans.). Cambridge, MA: Harvard University Press.

Foucault, M. (1972a). Histoire de la folie a l'age classique. Paris: Gallimard.

Foucault, M. (1972b). The archaeology of knowledge [1969]. New 
York: Pantheon Books.

Foucault, M. (1977). Language, counter-memory, practice: selected essays and interviews. In D. F. Bouchard (Ed.), D. F. Bouchard, \& S. Simon (Trans.). Ithaca, New York: Cornell University Press.

Foucault, M. (1980a). The history of sexuality, Vol. I. An introduction. New York: Vintage Books.

Foucault, M. (1980b). I'impossible prison: Recherches sur le système pénitentiare au XIXe siècle. In M. Perrot (Ed.), Paris: Seuil.

Foucault, M. (1984). Polemics, politics and problematizations, based on an interview conducted by Paul Rabinow. In L. Davis. (Trans.), Essential works of Foucault (Vol. 1), Ethics, New York: New Press. URL (last checked 10 October 2009)

http://foucault.info/foucault/interview.html

Foucault, M. (1985a). Discourse and truth: The problematization of parrhesia. In J. Pearson (Ed.), Evanston, IL: Northwestern University.

Foucault, M. (1985b). Michel Foucault, une histoire de la vérité. Paris: Editions Syros.

Foucault, M. (1986). The use of pleasure: The history of sexuality (Vol. 2). New York: Vintage.

Foucault, M. (1988). The Concern for Truth. In L. D. Kritzman (Ed.) Michel Foucault: Politics, philosophy, culture. Interviews and other writings, 1977-1984 (pp.255-267). Trans. A Sheridan. New York: Routledge.

Foucault, M. (1991a). Remarks on Marx: Conversations with Duccio Trombadori. In J. Goldstein and J. Cascaito (Eds. \& Trans.), New York: Semiotext(e).

Foucault, M. (1991b). Questions of method. In G. Burchell, C. Gordon, \& P. Miller (Eds.), The Foucault effect: Studies in governmentality (pp. 73-86). Hemel Hempstead: Harvester Wheatsheaf.

Franchi, S. (2004). Review of "Fearless Speech". Essays in Philosophy, 5. URL (last checked 10 October 2010)

http://commons.pacificu.edu/eip/vol5/iss2/11/

Freire, P. (1972). Pedagogy of the oppressed. Harmondsworth: Penguin.

Garland, D. (2001). The culture of control: Crime and social order in contemporary society. Chicago: University of Chicago Press.

Gordon, C. (1991). Governmental rationality. In G. Burchell, C. Gordon, \& P. Miller (Eds.), The Foucault effect: Studies in governmentality (pp. 1-48). Chicago: University of Chicago Press.

Gutting, G. (2008). Michel Foucault. In E. N. Zaita (Ed.), The Stanford encyclopedia of philosophy. (last checked 10 October 2011) http://plato.stanford.edu/entries/foucault/

Kaye, J., \& Martin, P. (2000). Safeguards for research using large-scale DNA collections. British Medical Journal, 321, 1146-1149. doi:10.1136/bmj.321.7269.1146

Koopman, C. (2007). Requiem for certainty: Deleuze on problematization (last checked 10 October 2011).

http://cwkoopman.wordpress.com/category/deleuze/

Law, J. (2004). After method: Mess in social science research. New York: Routledge.

Law, J. (2008a). On sociology and STS. The Sociological Review, 56, 623-649. doi:10.1111/j.1467-954X.2008.00808.x

Law, J. (2008b). Actor network theory and material semiotics. In B. S. Turner (Ed.), The new Blackwell companion to social theory (pp. 141-158, 3rd ed.). Oxford: Wiley-Blackwell.

Lazreg, M. (1988). Feminism and difference: The Perils of writing as a woman on women in Algeria. Feminist Issues, 14, 81-107.

May, T. (2006). The philosophy of Michel Foucault. Chesham: Acu- men.

Martin, L. H., Gutman, H., \& Hutton, P. H. (1988). Technologies of the self: A seminar with Michel Foucault. Amherst: University of Massachusetts Press.

Mol, A. (1999). Ontological politics: A word and some questions. In J. Law, \& J. Hassard (Eds.), Actor network theory and after (pp. 74-89) Oxford \& Malden, MA: Blackwell Publishers.

Mol, A. (2002). The body multiple: Ontology in medical practice. Durham and London: Duke University Press.

Montero, M., \& Sonn, C. C. (2009). Psychology of liberation: Theory and applications. New York: Springer.

Mort, F., \& Peters, R. (2005). Foucault recalled: Interview with Michel Foucault (conducted in 1979). New Formations, 10, 9-22.

Narayan, U. (1997). Restoring history and politics to "Third-World Traditions": Contrasting the colonialist stance and contemporary contestations of sati. In U. Narayan (Ed.), Dislocating cultures: Identities, traditions, and third-world feminism (pp. 41-81). New York: Routledge.

Narayan, U. (2000). Essence of culture and a sense of history: A feminist critique of cultural essentialism. In U. Narayan, \& S. Harding (Eds.), Decentering the center: Philosophy for a multicultural, postcolonial, and feminist world (pp. 80-100). Bloomington: Indiana University Press.

O’Farrell, C. (2005). Michel Foucault. London: Sage.

Osborne, T. (2003). What is a problem? History of the Human Sciences, 16, 1-17. doi:10.1177/0952695103164001

Oswick, C., Keenoy, T., Beverungen, A., Ellis, N., Sabelis, I., \& Yberna, S. (2007). Discourse, practice, policy and organizing: Some opening comments. Journal of Sociology and Social Policy, 27, 429432. doi:10.1108/01443330710835783

Pálsson, G., \& Rabinow, P. (2006). The Iceland controversy: Reflections on the transnational market of civic virtue. In A. Ong, \& S. J. Collier (Eds.), Global assemblages: Technology, politics, and ethics as anthropological problems (pp. 91-104). London: Blackwell.

Rabinow, P. (2003). Anthropos today: Reflections on modern equipment. Princeton and Oxford: Princeton University Press.

Rabinow, P. (2009). Foucault's untimely struggle: Toward a form of spirituality. Theory, Culture \& Society, 26, 25-44. doi:10.1177/0263276409347699

Rose, N. S. (2000). Powers of freedom: Reframing political thought. (2nd ed.). Cambridge, UK: Cambridge University Press.

Rose, N., \& Miller, P. (1992). Political power beyond the state: Problematics of government. British Journal of Sociology, 43, 172-205. doi:10.2307/591464

Rowse, T. (2009). The ontological politics of “closing the gaps”. Journal of Cultural Economy, 2, 33-48. doi:10.1080/17530350903063917

Simon, J. K. (1971). A conversation with Michael Foucault. Partisan Review, 38, 192-210.

Simpson, B. (2009). Pragmatism, Mead and the practice turn. Organization Studies, 30, 1329-1347. doi:10.1177/0170840609349861

St. Pierre, E. A. (2006). Scientifically based research in education: Epistemology and ethics. Adult Education Quarterly, 56, 239-266. doi:10.1177/0741713606289025

Veyne, P. (1997). Foucault revolutionizes history. In A. I. Davidson (Ed.), Foucault and his interlocutors (pp. 147-182). Chicago: University of Chicago Press.

Walters, W. (2004). Secure borders, safe haven, domopolitics. Citizenship Studies, 8, 237-260. doi:10.1080/1362102042000256989 